\title{
Profiles of Steady State Levels of Messenger RNAs Coding for Type I Procollagen, Elastin, and Fibronectin in Hamster Lungs Undergoing Bleomycin-induced Interstitial Pulmonary Fibrosis
}

\author{
Rajendra Raghow, Susan Lurie, Jerome M. Seyer, and Andrew H. Kang \\ Veterans Administration Medical Center and Departments of Pharmacology, Biochemistry, and Medicine, \\ University of Tennessee Center for Health Sciences, Memphis, Tennessee 38104
}

\begin{abstract}
We have characterized the messenger RNAs (mRNAs) coding for procollagen $\alpha 1(\mathrm{I})$, elastin, fibronectin, and actin in the lungs of Syrian golden hamsters by Northern blot analyses. While elastin, fibronectin, and $\beta$-actin were each coded for by a single mRNA species of 4.1 kilobases (kb), $9.1 \mathrm{~kb}$, and $2.1 \mathrm{~kb}$ in size, respectively, we identified a major $(5.4 \mathrm{~kb})$ and a minor $(6.5 \mathrm{~kb})$ procollagen $\alpha 1(I)$ mRNA species in the hamster lungs.

The mRNAs for the three extracellular matrix proteins showed increased accumulation followed by steady decline in the bleomycin-treated lungs. There were significant differences among the three mRNAs in the relative increase and the time of maximum accumulation. After reaching the peak levels between 2-3 wk posttreatment, the levels of procollagen $\alpha 1(I)$ and elastin mRNAs declined to near normal values around the fourth week. In contrast, the accumulation of fibronectin mRNA was maximum in the first week after bleomycin treatment. The procollagen $\alpha 1(I)$ mRNA accumulated most dramatically (sevenfold above the levels in the untreated animals) compared with a fivefold increase in mRNA coding for fibronectin. Elastin mRNA increased approximately twofold above the control values. $\mathrm{Nu}$ clear runoff transcription experiments demonstrated a selective increase in the rates of transcription of genes coding for procollagen $\alpha 1(I)$, fibronectin, and elastin; the extent of transcriptional stimulation of procollagen $\alpha 1(I)$ and fibronectin genes was significantly greater than that of elastin. Since the amount of actin mRNA, as well as the rate of transcription of actin gene(s), varied only slightly after bleomycin treatment, we conclude that the metabolism of mRNAs coding for extracellular matrix proteins may be preferentially perturbed during pulmonary fibrosis.
\end{abstract}

\section{Introduction}

Diffuse interstitial pulmonary fibrosis is a chronic condition characterized by reduced lung capacity and severely diminished gas exchange (1). Underlying these manifestations are major anatomical changes, the most prominent of which is progressive thickening of alveolar walls that contain large numbers of inflammatory cells and fibroblasts. In addition to changes in the cellular composition, there are also characteristic changes in the composition of extracellular matrix (2); increased net synthesis and/or deposition of interstitial collagens $(3-7)$, elastin $(8,9)$,

\footnotetext{
Address correspondence to Dr. Raghow, Veterans Administration Medical Center, Research Service, 1030 Jefferson Ave., Memphis, TN 38104.

Received for publication 19 December 1984 and in revised form 23 July 1985.
}

The Journal of Clinical Investigation, Inc.

Volume 76, November 1985, 1733-1739 and proteoglycans $(10,11,12)$ in the lungs have been reported in experimentally induced pulmonary fibrosis. There are several reports of an increased collagen content of fibrotic lungs in humans $(2,13,14)$; a recent study also reported increased levels of fibronectin in the bronchoalveolar lavage fluid of human lungs from patients suffering from idiopathic pulmonary fibrosis (15). The exact relationship between altered extracellular matrix and concomitant changes in the cellular composition in the lungs undergoing fibrosis is unclear. In addition to providing a structural role, extracellular matrix may directly influence cellular gene expression and may mediate the cell interaction in the tissues (2) and, therefore, may be responsible for characteristic changes in the histology that accompany interstitial pulmonary fibrosis.

The changes in the various components of extracellular matrix during pulmonary fibrosis have been studied in considerable detail. However, the precise mechanism(s) that lead to increased deposition of extracellular matrix are far from clear. The polypeptide components of extracellular matrix could be potentially regulated at a number of transcriptional and posttranscriptional steps (2). Therefore, a necessary prerequisite to fully understand the altered metabolism of various components of the extracellular matrix would be to analyze the contribution of individual regulatory steps mediating the synthesis and degradation of these polypeptides. The primary objective of the present study was to outline the profiles of accumulation of messenger RNAs (mRNAs) ${ }^{1}$ coding for three important constituents of extracellular matrix, namely type I collagen, elastin, and fibronectin. These changes in the accumulation of mRNAs for specific polypeptide components of extracellular matrix were analyzed in relation to overall $\mathrm{mRNA}$ metabolism; the latter was monitored by measuring the accumulation of cytoplasmic $\beta$-actin mRNA, a ubiquitous eukaryotic $\mathrm{mRNA}$. Using radiolabeled recombinant DNA probes, sequential changes in the metabolism of individual mRNA species were analyzed in the lungs of hamsters after a single dose of endotracheal instillation of bleomycin.

\section{Methods}

Bleomycin treatment and tissue preparation. 10-wk-old Syrian golden hamsters were treated with bleomycin (Bristol Laboratories Div., BristolMyers, Co., Syracuse, NY) by intratracheal instillation (1.0 U/lung in $0.5 \mathrm{ml}$ of saline). The lungs of control age-matched animals were similarly instilled with saline solution. At different days, between 1 and $42 \mathrm{~d}$ after bleomycin instillation, hamsters were anesthesized with $0.1 \mathrm{ml}$ of Nembutal $(50 \mathrm{mg} / \mathrm{ml})$ and lungs were dissected free of large bronchii and blood vessels. Lung tissue was minced with sterile scalpel and known

1. Abbreviations used in this paper: $\mathrm{BAL}$, bronchoalveolar lavage; $\mathrm{CsCl}$, Cesium chloride; DME, Dulbecco's modified Eagle's medium; kb, kilobase; mRNA, messenger RNA; $\mathrm{NaCl} / \mathrm{Cit}, 0.15 \mathrm{M} \mathrm{NaCl} / 0.015 \mathrm{M}$ trisodium citrate; tRNA, transfer RNA. 
aliquots were separated for various biochemical parameters as described below.

Determination of rates of protein synthesis and total protein and DNA content. Essentially, the detailed protocols described by Clark and colleagues (3) were followed with minor modifications to evaluate noncollagenous and collagenous protein synthesis. Tissue minces $(200 \mathrm{mg})$ were incubated in $5.0 \mathrm{ml}$ of Dulbecco's modified Eagle's medium (DME) containing $10 \%$ fetal calf serum, penicillin $(200 \mathrm{U} / \mathrm{ml})$, Streptomycin $(200 \mathrm{mg} / \mathrm{ml}), \beta$-aminopropionitril $(80 \mu \mathrm{g} / \mathrm{ml})$, and ascorbate $(50 \mu \mathrm{g} / \mathrm{ml})$. After $1 \mathrm{~h}$ of incubation at $37^{\circ} \mathrm{C}$ in a shaker, medium was replaced with fresh $5.0 \mathrm{ml} \mathrm{DME}$ containing $25 \mu \mathrm{Ci}$ of $\left[{ }^{3} \mathrm{H}\right]$ proline or $\left[{ }^{35} \mathrm{~S}\right]$ methionine and incubation continued for another $4 \mathrm{~h}$. At the end of the incubation, tissue was taken up in $2.0 \mathrm{ml}$ of $0.5 \mathrm{M}$ acetic acid and homogenized; $100-\mu l$ aliquots were frozen in liquid $\mathrm{N}_{2}$ for determination of total DNA and protein contents. The remaining sample was processed as described earlier (16) and was hydrolyzed with $6 \mathrm{~N} \mathrm{HCl} ;\left[{ }^{3} \mathrm{H}\right]$ proline and $\left[{ }^{3} \mathrm{H}\right]$ hydroxyproline contents were determined by the protocols described in detail previously (16). Determination of total protein was done by the modified Lowry procedure (17) and DNA content was measured according to Burton (18).

Extraction and selection of poly $A^{+} m R N A$. Lungs were frozen quickly in liquid $\mathrm{N}_{2}$ and pulverized by a motor-driven electric homogenizer. The dry powder was brought up in five times the volumes of the RNA extraction buffer ( $6 \mathrm{M}$ guanidium thiocyanate; $5 \mathrm{mM}$ sodium citrate, $\mathrm{pH}$ $7.0 ; 0.1 \mathrm{M} \beta$-mercaptoethanol, and $0.5 \%$ sodium sarkosinate) and homogenized in a glass homogenizer (19). To each $2.5 \mathrm{ml}$ of homogenate, $1.0 \mathrm{~g}$ of Cesium chloride $(\mathrm{CsCl})$ was added and the extract was layered on $3.0 \mathrm{ml}$ of $5.7 \mathrm{M} \mathrm{CsCl}$ (made in $0.1 \mathrm{M}$ EDTA, pH 7.5) cushion in a SW-40 rotor and centrifuged at $35,000 \mathrm{rpm}$ for $12 \mathrm{~h}$ at $20^{\circ} \mathrm{C}$. RNA pellet was dissolved in buffer (10 mM Tris-HCl, $\mathrm{pH} 7.4 ; 5 \mathrm{mM}$ EDTA and $1.0 \%$ sodium dodecyl sulfate), extracted with $4: 1$ mixture of $\mathrm{CHCl}_{3} / 1$ Butanol and precipitated from the aqueous phase (20). A small amount of proteins and proteoglycans pellet through the $\mathrm{CsCl}$ cushion; extraction with $\mathrm{CHCl}_{3} / 1$-Butanol effectively removes these materials ( $R$. Raghow, unpublished observations). RNA pelleted from ethanol step was taken up in water and fractionated on oligo (dT) cellulose (T3; Collaborative Research, Inc., Waltham, MA) according to the published procedures (21).

Northern blot and dot blot analysis of mRNAs. Poly $\mathrm{A}^{+}$mRNA (ranging from 1 to $10 \mu \mathrm{g}$ ) was denatured in $50 \%$ formamide and electrophoresed in $1 \%$ agarose gels containing $2.2 \mathrm{M}$ formaldehyde. After electrophoresis, RNA was transferred to nitrocellulose paper without prior treatment, baked at $80^{\circ} \mathrm{C}$ under vacuum, and either stored under vacuum or immediately subjected to prehybridization $(16,22)$. The prehybridization and hybridization protocols were essentially as described previously (16). Recombinant DNA plasmids were labeled with $\left.{ }^{32} \mathrm{P}\right]$ nucleoside triphosphates by nick-translation (16) to high specific activity $\left(1-5 \times 10^{8} \mathrm{cpm} / \mu \mathrm{g}\right)$. Both Northern and dot blots were hybridized under conditions of excess probe; a filter containing a twofold dilution series $(10-0.06 \mu \mathrm{g})$ of hamster RNA was hybridized to individual probes to show that the hybridization of these probes over a 160 -fold range was linear (R. Raghow, unpublished results). The clone containing genomic sequences coding for sheep elastin (23) were hybridized at $37^{\circ} \mathrm{C}$, instead of $42^{\circ} \mathrm{C}$, in hybridization buffer for $12-24 \mathrm{~h}$. The washing and autoradiography was done according to the method of Thomas (22). Nitrocellulose blots were washed in boiling water for $10 \mathrm{~min}$ to remove the probes (24); blots were then subjected to a second round of prehybridization and hybridization with a second probe.

For dot blots, poly $\mathrm{A}^{+} \mathrm{mRNA}$ was taken up in denaturation buffer ( $50 \%$ formamide, $6 \%$ formaldehyde, $20 \mathrm{mM}$ phosphate buffer, $\mathrm{pH} 7.0$ ), heated to $60^{\circ} \mathrm{C}$ for $5 \mathrm{~min}$, and chilled in ice water for $1 \mathrm{~min}$. Each RNA sample was mixed with an equal volume of $20 \times \mathrm{NaCl} / \mathrm{Cit}(0.15 \mathrm{M} \mathrm{NaCl} /$ $0.015 \mathrm{M}$ trisodium citrate $=1 \times$ ). Beginning with $2 \mu \mathrm{g}$ mRNA in 100 $\mu 1$, twofold serial dilutions were made by adding $10 \times \mathrm{NaCl} / \mathrm{Cit}, 3 \%$ formaldehyde, $20 \mathrm{mM}$ phosphate buffer, $\mathrm{pH}$ 7.0. Total RNA content of each serially-diluted sample was maintained at $2 \mu \mathrm{g} / 100 \mu \mathrm{l}$ by adding the appropriate amount of calf liver transfer RNA (tRNA). The samples were applied to a nitrocellulose sheet premoistened with $10 \times \mathrm{NaCl} / \mathrm{Cit}$ using a Hybridot Apparatus (Bethesda Research Laboratories, Gaithersburg, MD). Baking, prehybridization, and hybridization protocols were similar to those for Northern blots. The results from the dot blots were quantitated by densitometric scanning of autoradiograms.

Runoff transcription. Previously published techniques $(16,25)$ with minor modifications were used for the isolation of nuclei, in vitro transcription, and subsequent determination of the rates of transcription of hybridization. Nuclei from control or bleomycin-treated lungs were either used immediately after isolation or stored at $-70^{\circ} \mathrm{C}$ in $25 \%$ glycerol, 60 $\mathrm{mM} \mathrm{KCl}, 15 \mathrm{mM}$ Tris- $\mathrm{HCl}, \mathrm{pH}$ 7.5. To start transcription, nuclei (100$150 \mu \mathrm{g}$ of DNA) were incubated in a $100-\mu \mathrm{l}$ reaction mix that contained $10 \%$ glycerol, $50 \mathrm{mM}$ Tris- $\mathrm{HCl}, \mathrm{pH} 8.0,5 \mathrm{mM} \mathrm{MgCl}, 1 \mathrm{mM}$ each of ATP, GTP, and CTP, and $250 \mu \mathrm{Ci}$ of $\left[\alpha-{ }^{32} \mathrm{P}\right] \mathrm{UTP}$ at $25^{\circ} \mathrm{C}$ for $30 \mathrm{~min}$. Under these conditions, the $\left[\alpha-{ }^{32} \mathrm{P}\right] U T \mathrm{P}$ showed a linear incorporation for $\sim 25-30 \mathrm{~min}$, after which, in some cases, there was an actual decline in the TCA-precipitable radioactivity. An identical aliquot of nuclei was also incubated with $\alpha$-amanitin $(80 \mu \mathrm{M})$ to determine the specificity of RNA polymerase II mediated transcription. Radiolabeled RNA was extracted and hybridized to DNA immobilized on nitrocellulose filters. In each case, $5 \mu \mathrm{g}$ of linearized, alkali-denatured, plasmid DNA was immobilized on nitrocellulose filter disks $(0.5-\mathrm{cm}$ diameter). For determining nonspecific background, $5 \mu \mathrm{g}$ of bacteriophage $\lambda$ charon 4A DNA was hybridized to radiolabeled run-off transcripts. Conditions for the preparation of nitrocellulose filters, prehybridization, hybridization at $42^{\circ} \mathrm{C}$, and washing have been described previously (16). Since hybridization for more than $24 \mathrm{~h}$ did not result in increased signal intensity, we believe that the maximum hybridization was achieved under these conditions.

Preparation of recombinant DNA probes. For type I procollagen mRNA analyses, we used plasmid HF677, a recombinant clone containing $1.8 \mathrm{~kb}$ complement of human $\alpha \mathrm{l}(\mathrm{I})$, procollagen mRNA (26). The HF677 was kindly given to us by Dr. F. Ramirez, Rutgers University Medical School, Piscataway, NJ. A sheep genomic DNA clone was used to measure elastin mRNA levels; this clone construct contains $1.3 \mathrm{~kb}$ genomic DNA insert in pUC9 and codes for the 3'-terminal portion of the elastin mRNA $(23,27)$. The elastin clone was obtained from Dr. J. Davidson, University of Utah Medical School, Salt Lake City, UT. Dr. Richard Hynes, Massachusetts Institute of Technology, Cambridge, MA generously provided a cDNA clone of rat fibronectin $(27,28)$ for analysis of fibronectin mRNAs. Finally, a full-length cDNA clone of chicken cytoplasmic $\beta$-actin (29) was obtained from Dr. D. W. Cleveland, Johns Hopkins University School of Medicine, Baltimore, MD. We obtained various Escherichia coli strains harboring appropriate plasmids as agar stab cultures. Supercoiled plasmid DNA was purified according to published procedures (30). All plasmid preparations were tested for the characteristics of the inserted DNA by digestion with appropriate restriction endonucleases and gel electrophoresis. For most Northern and dot blot analyses, intact supercoiled plasmid DNA was nick-translated and served as a probe; in some experiments, the inserted eukaryotic DNA was excised from the vector and nick-translated to increase the specific activity of the probe.

\section{Results}

Pathology. Consistent with previously published data $(3,5,6)$, the lungs of animals receiving intratracheal instillation of bleomycin underwent physiological and anatomical changes characteristic of interstitial pulmonary fibrosis. Examination of lung sections at various times after treatment revealed two partially superimposable, yet distinct, phases of fibrogenesis. The inflammatory phase, evident between 4-15 d after treatment, was characterized by edematous congestion, slight hemorrhage, and tissue infiltration with polymorphonuclear and mononuclear cells. The fibrotic phase apparently began in the third week and was accompanied by considerably reduced numbers of inflammatory cells and a concomittant increase in the number of fi- 
broblasts. Peribronchial foci of fibrosis were evident consistently in tissue sections $21 \mathrm{~d}$ after bleomycin treatment. Although the number of fibrotic lesions steadily increased with time, even as late as $42 \mathrm{~d}$ posttreatment, fibrosis was only in patches.

Protein synthesis. We investigated the relative rates of collagenous and noncollagenous protein synthesis in lung explant cultures at various times after bleomycin treatment. As shown in Fig. 1, the rate of total protein synthesis in the bleomycintreated lungs from the fourth day onward peaked at $165 \%$ above the untreated controls around day 14. Although the pattern of collagenous protein synthesis, as measured by the rate of formation of radiolabeled 4-hydroxyproline in the lung explants (3), resembled the pattern of total protein synthesis (Fig. 1), there were significant quantitative differences. In contrast to total protein synthesis (less than twofold stimulation in treated lungs), the collagenous protein synthesis was stimulated nearly fivefold above the control levels (Fig. 1). The maximum stimulation of collagenous protein synthesis was apparent at day 14; the rate declined steadily thereafter, reaching a plateau around day 28 . Note, however, that the rate of total and collagen-specific protein synthesis remained slightly higher than the control animals for the remainder of the experiment.

Characterization of collagen, elastin, ard fibronectin $m R N A s$ from hamster lungs by Northern blotting. Since none of the probes used in these experiments were of hamster origin, it was important to test their suitability for measurements of $\mathrm{mRNA}$ accumulation in the hamster lung. We investigated the hybridization conditions for Northern blot analysis and characterized the mRNA species coding for collagen, elastin, and fibronectin. All recombinant DNA clones, except elastin, were hybridized to specific mRNA species under standard hybridization conditions. For elastin, the best hybridization was obtained at $37^{\circ} \mathrm{C}$ (in contrast to $42^{\circ} \mathrm{C}$ under standard reaction conditions; see Methods).

The human procollagen $\alpha \mathrm{l}$ (I) cDNA plasmid hybridized to two mRNA species of $5.4 \mathrm{~kb}$ and $6.5 \mathrm{~kb}$ size in the hamster lung (Fig. $2 A$ ). The 5.4-kb mRNA species represents $>80 \%$ of procollagen $\alpha 1$ (I) mRNA in the hamster lungs (unpublished obser-

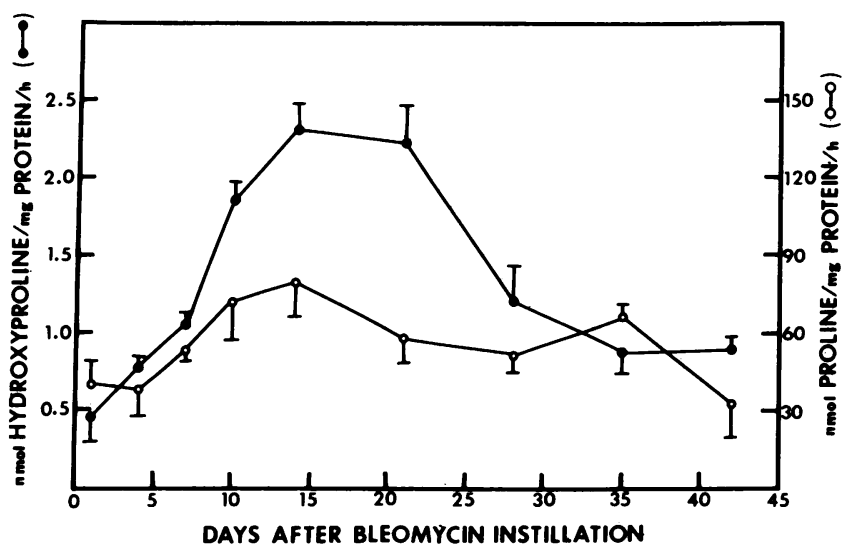

Figure 1. Temporal changes in the rates of collagenous and noncollagenous protein synthesis in bleomycin-treated hamster lungs. Lung explant cultures ( $200 \mathrm{mg}$ fresh weight) from individual animals removed at the denoted intervals after bleomycin treatment were incubated in DME containing $25 \mu \mathrm{Ci} / \mathrm{ml}$ of $\left[{ }^{3} \mathrm{H}\right]$ proline for $4 \mathrm{~h}$. The rates of $\left[{ }^{3} \mathrm{H}\right]$ hydroxyproline synthesis (as a measure of collagenous protein synthesis) and $\left[{ }^{3} \mathrm{H}\right]$ proline incorporation (as an indicator of total protein synthesis) were determined as outlined in Methods. The average values of three determinations with standard deviations are shown.

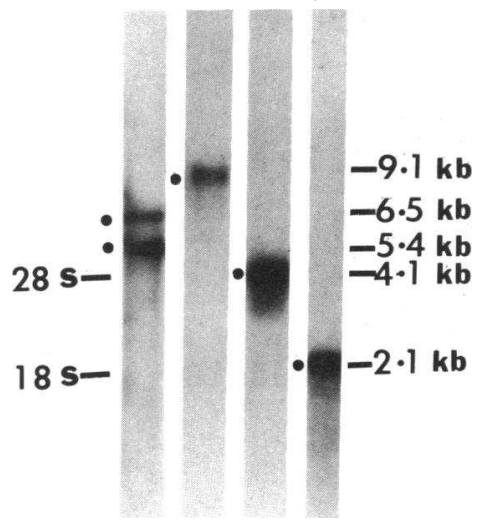

A B C D
Figure 2. Identification of mRNA species coding for pro $\alpha 1$ (I) fibronectin, elastin, and cytoplasmic $\beta$-actin in hamster lungs. $10 \mu \mathrm{g}$ of poly $\mathrm{A}^{+}$mRNA from hamster lungs was electrophoresed on $1 \%$ agarose in 2.2 $M$ formaldehyde, transferred to nitrocellulose, and hybridized to nick-translated probes $\left(1-5 \times 10^{8}\right.$ $\mathrm{cpm} / \mu \mathrm{g}$ ) as described in detail in Methods. The $28 \mathrm{~S}$ and $18 \mathrm{~S}$ ribosomal RNA markers were located by ethidium bromide staining.

The molecular weights of mRNAs are shown in kilobases $(\mathrm{kb}) .(A)$ pro $\alpha 1(\mathrm{I}) ;(B)$ fibronectin; $(C)$ elastin; and $(D)$ cytoplasmic $\beta$-actin.

vations). Two mRNAs species for procollagen $\alpha$ l(I)-chains have previously been identified in human $(26,31)$, mouse $(32)$, rat (16), and chicken cells (33). The relative abundance of the two size classes and their apparent molecular weights differ in different species.

The rat fibronectin cDNA plasmid identified a single mRNA species in hamster lung of $\sim 9.1 \mathrm{~kb}$ size (Fig. $2 B$ ). The sheep genomic clone of elastin also hybridized to a single mRNA of $4.1 \mathrm{~kb}$ in the hamster lung (Fig. $2 C$ ). Finally, the use of chicken cDNA clone for cytoplasmic $\beta$-actin identified a single mRNA of $2.1 \mathrm{~kb}$ in hamster (Fig. $2 \mathrm{D}$ ). Our full-length cDNA clone for cytoplasmic $\beta$-actin (which shares coding sequences with $\gamma$-actin mRNA; ref. 29) would be expected to detect $\beta$-actin, as well as $\gamma$-actin mRNAs. Since the two mRNAs have been shown to be identical in size (29), we were unable to detect the individual $\beta$ actin and $\gamma$-actin mRNAs in Northern blots. It was evident, however, that these recombinant probes were sufficiently specific for the type of analysis we wished to undertake.

Profiles of procollagen $\alpha 1(I)$ elastin, fibronectin, and actin mRNA accumulation in bleomycin-treated hamster lungs. The relative amounts of specific $m R N A s$ from hamsters at various times after bleomycin treatment were determined by dot blot hybridization using poly $\mathrm{A}^{+} \mathrm{mRNA}$. In a preliminary experiment we analyzed the relative distribution of sequences coding for procollagen $\alpha 1(\mathrm{I})$, fibronectin, elastin, and $\beta$-actin in the poly $\mathrm{A}^{+}$and poly $\mathrm{A}^{-}$fractions of the hamster lungs 0,2 , and $4 \mathrm{wk}$ after bleomycin. Since there was no measureable change in the ratio of the various mRNAs in the two fractions ( $R$. Raghow, unpublished observations), we believe that our measurements using poly $\mathrm{A}^{+}$mRNA accurately represent the overall mRNA metabolism of the fibrotic lung. Fig. 3 depicts one of the two dot blot hybridizations used to derive quantitative data in mRNA abundances shown in Fig. 4. Densitometric scanning and direct scintillation counting of nitrocellulose representing an individual mRNA spot was used to determine quantitative changes in the relative mRNA abundances. As shown in Fig. 4, the amount of procollagen $\alpha \mathrm{l}(\mathrm{I}) \mathrm{mRNA}$ in the lungs of bleomycin-treated hamsters was higher than controls starting from very early times after treatment ( $7 \mathrm{~d}$ ). The procollagen $\alpha 1$ (I) mRNA continued to increase until $14 \mathrm{~d}$ after treatment, when it was approximately sevenfold higher relative to untreated hamsters; the amount of procollagen $\alpha 1$ (I) mRNA declined thereafter and fell a little below the control level after $35 \mathrm{~d}$ after treatment (Fig. 4). 

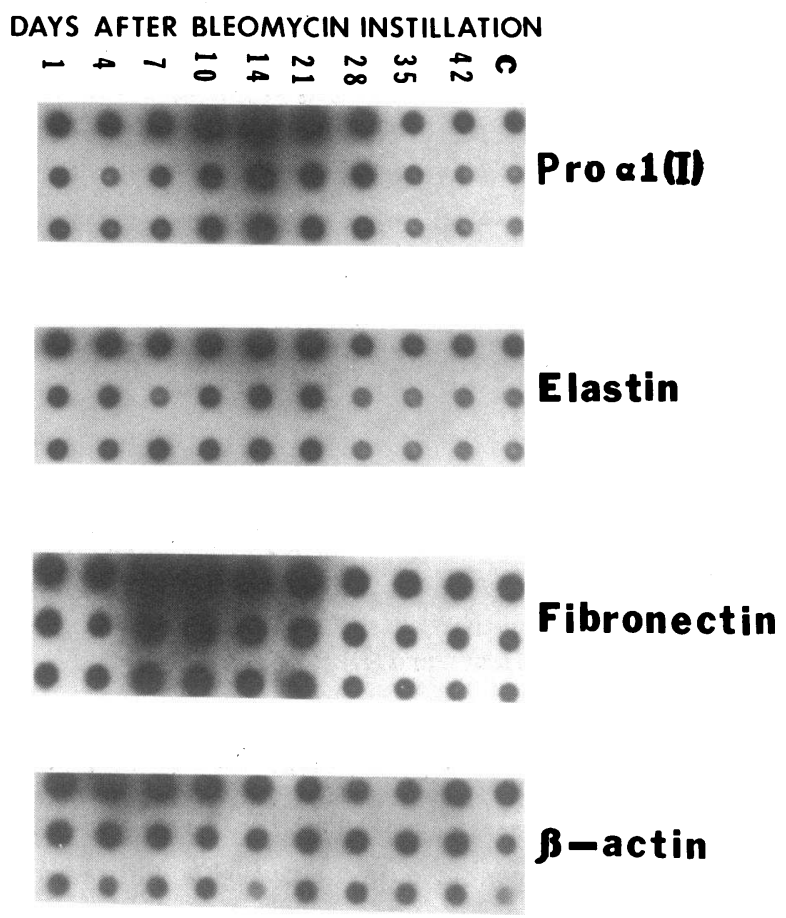

Figure 3. Autoradiograms depicting dot-blot hybridization of hamster lung mRNAs. Twofold serial-dilutions of poly $\mathrm{A}^{+}$RNA samples from control $(C)$ and bleomycin-treated hamster lungs were applied to nitrocellulose filters, hybridized to nick-translated plasmids, and autoradiographed as described in Methods. Top, middle, and bottom rows in each sample represent $5.0,2.5$, and $1.25 \mu \mathrm{g}$ of poly $\mathrm{A}^{+} \mathrm{RNA}$, respectively. Autoradiographic exposures were varied to allow optimum distinction in abundance changes and, therefore, the intensity differences between different samples cannot be compared directly. The quantitative data on relative abundance changes (Fig. 4) were obtained by combining densitometry and direct scintillation counting.

The mRNA coding for elastin, another abundant extracellular matrix protein of the lung, also exhibited a pattern of increased accumulation analogous to procollagen $\alpha 1$ (I) mRNA in the lungs of bleomycin-treated animals (Fig. 4). However, the extent of increase in the content of elastin mRNA of bleomycintreated lungs was much less; at the time of maximum accumulation (14 d), elastin mRNA showed about twofold increase, followed by a steady decline, reaching the level found in the untreated hamsters at $21 \mathrm{~d}$ posttreatment (Fig. 4).

The temporal profile of fibronectin mRNA accumulation in bleomycin-treated hamster lungs was obtained by dot blot analysis using a rat fibronectin cDNA clone (26). Bleomycin-treated lungs rapidly accumulated increased amounts of fibronectin mRNA (Fig. 4); after reaching a greater than fivefold increase above the untreated controls at day 7 , the mRNA level steadily declined to approximately normal values in the third week (Fig. 4).

Finally, to examine the sequential changes in the accumulation of overall cellular mRNAs, we determined the relative accumulation of actin mRNA. Our full-length $\beta$-actin cDNA probe is very likely detecting the $\beta$-actin, as well as $\gamma$-actin mRNA sequences, since the coding sequences of these two mRNAs are highly conserved (29). It was evident that the content of actin mRNAs varied only slightly between bleomycin-treated and untreated hamster lungs during the course of this experiment (Fig. 4).

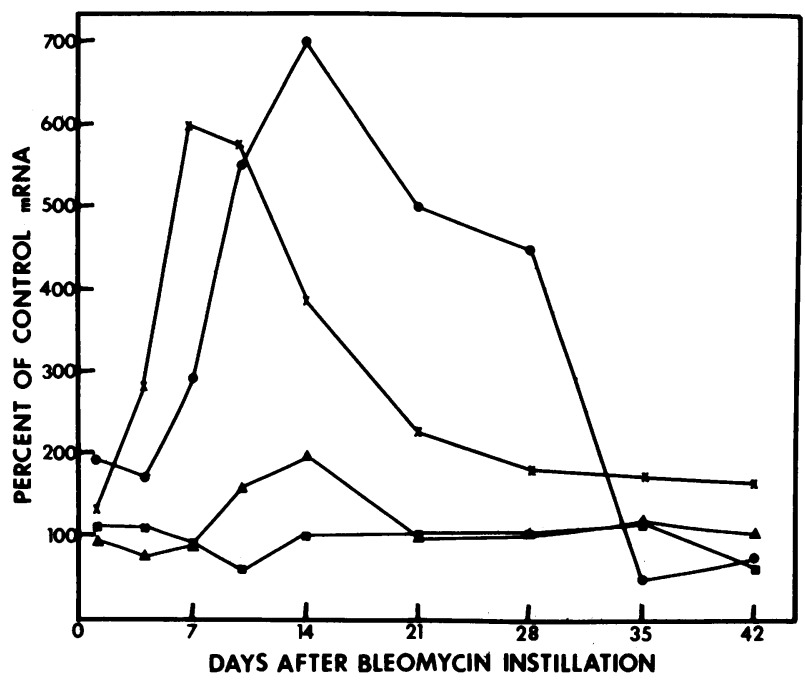

Figure 4. Quantification of individual mRNAs coding for extracellular matrix proteins in hamster lungs at various times after endotracheal administration of bleomycin. Equal amounts of poly $\mathrm{A}^{+} \mathrm{mRNA}$ from control or bleomycin-treated lungs was spotted in twofold serial dilutions and hybridized to nick-translated DNA probes as shown in Fig. 3 and described in Methods. Quantitation of mRNA abundance was done by two methods. Individual spots from the autoradiograph were scanned densitometrically and areas under the peaks were calculated. In addition, we measured radioactivity directly in different spots by scintillation spectrometry. The results are expressed as percent change in the mRNAs compared with untreated controls. $\bullet$, Procollagen $\alpha 1(\mathrm{I}) ; \times$, fibronectin; $\Delta$, elastin; and $\mathbf{n}, \beta$-actin.

Rates of transcription of proal(I), fibronectin, elastin, and actin genes in bleomycin-treated hamster lungs. To evaluate whether the changes in the mRNA accumulation were mediated through increased transcription, we determined the rates of transcription of individual mRNAs in the nuclei from hamster lungs by runoff transcription assays. As expected, a virtual absence of hybridizable transcripts made in the presence of $80 \mu \mathrm{M}$ $\alpha$-amanitin suggested that all four of these genes were transcribed by RNA polymerase II (data not shown). As shown in Table I, both fibronectin and procollagen $\alpha 1$ (I) genes were transcribed at an enhanced rate (two- to fourfold) in the bleomycin-treated lungs in the first 2 wk. In all samples at day 35 (a time when the steady-state levels of mRNAs return to nearly control values; Fig. 4), the rates of transcription of fibronectin and procollagen $\alpha 1$ (I) also returned to the control value. The rates of transcription of elastin and $\beta$-actin showed a small (30-70\% above untreated controls), but reproducible, increase, which suggests measurable perturbations in the transcription of these genes (Table I).

\section{Discussion}

Using recombinant DNA probes, we have investigated the pattern of accumulation of mRNAs coding for procollagen $\alpha 1(\mathrm{I})$, elastin, fibronectin, and $\beta$-actin in hamster lungs after endotracheal administration of bleomycin. While the transcription of all three genes of extracellular matrix was found to be elevated after bleomycin treatment, there were significant quantitative and qualitative differences. Both the extent of transcriptional elevation and the time of maximum mRNA accumulation were different for the three genes examined. The level of fibronectin mRNA increased rapidly, reaching a peak at day 7 , while the 
Table I. Rates of Transcription of Pro $\alpha \mathrm{l}(\mathrm{I})$, Fibronectin, Elastin, and $\beta$-Actin Genes in Nuclei Isolated from Bleomycin-treated Hamster Lungs

\begin{tabular}{|c|c|c|c|c|c|c|c|c|}
\hline \multirow[b]{2}{*}{ Probe } & \multicolumn{2}{|l|}{ Day 1} & \multicolumn{2}{|l|}{ Day 7} & \multicolumn{2}{|l|}{ Day 14} & \multicolumn{2}{|l|}{ Day 35} \\
\hline & Control & Bleo & Control & Bleo & Control & Bleo & Control & Bleo \\
\hline Fibronectin & $61.3^{*}$ & 73.6 & 57.9 & 187.2 & 64.1 & 179.5 & 58.9 & 67.1 \\
\hline Pro $\alpha 1(\mathrm{I})$ & 58.6 & 61.3 & 47.8 & 124.3 & 65.9 & 270.19 & 48.7 & 39.8 \\
\hline Elastin & 23.2 & 26.7 & 31.8 & 41.3 & 28.4 & 47.7 & 34.3 & 48.0 \\
\hline$\beta$-Actin & 96.7 & 99.4 & 102.3 & 138.8 & 120.1 & 168.24 & 99.2 & 126.9 \\
\hline$\lambda-4 \mathrm{~A}$ & 1.3 & 2.2 & 2.0 & 1.9 & 1.7 & 2.3 & 2.1 & 1.8 \\
\hline
\end{tabular}

Nuclei isolated from the lungs of control $(0.5 \mathrm{ml}$ of saline administered i.t.) or bleomycin-treated ( $1 \mathrm{U}$ of bleomycin in $0.5 \mathrm{ml}$ of saline administered i.t.) animals were subjected to runoff transcription as described in Methods. Radiolabeled nascent transcripts $\left(5-7 \times 10^{6} \mathrm{cpm}\right)$ from each assay were hybridized to $10 \mu \mathrm{g}$ of linearized recombinant plasmid DNAs immobilized on nitrocellulose. After hybridization the filters were counted in a scintillation spectrometer; a machine background of $37 \mathrm{cpm}$ was subtracted from all the values. * Average values of radioactive runoff transcripts bound from three separate determinations are shown as parts per million (PPM). There was $<10 \%$ variation in the radiolabeled runoff transcripts bound to immobilized DNA in different experiments. The ratio of bleomycin/control for each assay is shown in the parentheses.

accumulation of elastin and collagen mRNAs peaked at about 2 wk after treatment. Furthermore, while the levels of fibronectin and procollagen $\alpha 1$ (I) mRNAs increased six- to sevenfold above the controls at the peak time, the levels of elastin mRNA did not exceed twofold in two separate experiments. The profiles of mRNA accumulation reflect both the number of cell type(s) responsible for their synthesis and/or a preferential transcription of specific gene(s). For instance, a rapid change in the rate of accumulation of fibronectin mRNAs may partly be due to increased numbers of inflammatory cells, especially macrophages (a cell type known to actively synthesize and secrete fibronectin) in the bleomycin-treated lungs. The recruitment and expansion of fibroblasts, cells primarily responsible for collagen synthesis, is a postinflammatory phase of the fibrotic process $(2,7)$. Thus, the profiles of procollagen mRNA accumulation are consistent with the changing cellular composition of the bleomycin-treated lungs.

The relationship between the temporal changes in the amount of mRNA coding for three representatives of extracellular matrix and the corresponding profiles of the putative polypeptide products remains incompletely resolved. This is mainly because there are no analogous data on the synthesis of the individual polypeptide products after the induction of experimental fibrosis. Even for collagens, the most extensively analyzed representative of the extracellular matrix, there is no information on the rate of synthesis of individual collagen polypeptides chains (see ref. 2 for extensive review). The increase in the rate of collagenous protein synthesis (fivefold) appeared to correspond with a change in the amount of procollagen $\alpha 1$ (I) mRNA (sevenfold). A similar increase was also obtained for procollagen $\alpha 2(\mathrm{I})$ mRNA (our unpublished results), suggesting that the procollagen $\alpha 1$ (I) and procollagen $\alpha 2$ (I) genes are regulated coordinately. Clark et al. (3) have shown an increase in the intracellular proline pool size in bleomycin-treated hamster lungs. Since we did not correct for the changes in the intracellular pool size of proline, the protein synthetic rates may be underestimated. Therefore, the corre- spondence between the rate of collagenous protein synthesis and the steady-state levels of mRNAs may be even better.

The pattern of accumulation of elastin mRNA closely corresponds to the pattern of elastin accumulation reported previously $(2,7,9)$. Based on several studies showing that the elastin synthesis in tissues is mainly regulated at the transcriptional level $(2,27)$, we believe that the net accumulation of elastin observed during fibrosis $(2,7)$ is primarily due to increased rates of elastin mRNA synthesis. However, in the absence of direct measurements of rates of elastin synthesis, this conclusion remains tentative.

The fibronectin mRNA accumulation peaked at day 7 and declined thereafter. It is interesting that the levels of fibronectin protein in the bronchoalveolar lavage (BAL) fluid of bleomycin treated lungs increased about threefold that of control around day 10 (our unpublished observations). However, in contrast to mRNA levels, the fibronectin levels in the BAL did not decline in the later times (Raghow, R., unpublished observations). Increased levels of fibronectin in the BAL fluid have been observed in patients with interstitial pulmonary fibrosis (15). The apparent discordance between the levels of mRNA and protein suggests that posttranscriptional regulatory mechanisms may also be operative.

Finally, surprisingly while the overall protein synthesis showed an increase of about twofold, there was insignificant change in the accumulation of actin mRNA in the bleomycintreated lungs. It is difficult to explain why the level of cytoplasmic actin mRNA did not strictly correspond with the pattern of total protein synthesis. Obviously, these observations need further verification by alternative approaches (i.e., in situ hybridization of various radiolabeled recombinant DNA probes) before final conclusions can be drawn.

The experimental observations from nuclear runoff transcription assays presented here strongly suggest that the overriding control of extracellular matrix biosynthesis during bleomycininduced pulmonary fibrosis is exerted at the transcriptional level. 
The precise nature of the stimuli that alter the rates of transcription of genes of extracellular matrix preferentially remains to be elucidated. In this context, the possible role of various soluble mediator(s) (34-37) capable of regulating the expressions of genes coding for extracellular matrix need to be investigated further.

Finally, a note of caution should be added to the above discussion. The data correlating the steady-state levels of numerous mRNAs and corresponding changes in the rates of their polypeptide products show clearly that the transcriptional control is the primary regulatory step in eukaryotic gene expression. However, several recent studies show convincing evidence for posttranscriptional controls (38-41). Therefore, although the steadystate levels of mRNAs for procollagen $\alpha 1$ (I), fibronectin, and elastin in bleomycin-treated lungs correlated well with perturbation in the transcriptional status of these genes, the biosynthetic rates of individual polypeptide species must be determined before the precise control mechanisms can be pinpointed.

\section{Acknowledgments}

We thank Yolanda Towner, Jennifer Minton, and Quinn Cain for expert technical assistance, and Jeannie Rogers for preparation of the manuscript. We are grateful to Dr. F. Ramirez, Dr. J. Davidson, Dr. R. Hynes, and Dr. D. Cleveland for generously providing the recombinant plasmids.

This work was supported by the Veterans Administration, and in part by National Institutes of Health grant R01-AA03732. Dr. Lurie was supported by National Institutes of Health training grant AM07317.

\section{References}

1. Turino, G. M. 1980. The assessment of functional impairment in pulmonary interstitial fibrosis. In Pulmonary Diseases and Disorders. A. P. Fishman, editor. McGraw-Hill, Inc., New York. 725-732.

2. Clark, J. G., C. Kuhn, J. A. McDonald, and R. P. Mecham. 1983. Lung connective tissue. Ann. Rev. Connective Tissue Res. 10:249-331.

3. Clark, J. G., J. E. Overton, B. A. Marino, J. Vitto, and B. C. Starcher. 1980. Collagen biosynthesis in bleomycin-induced pulmonary fibrosis in hamsters. J. Lab. Clin. Med. 96:943-953.

4. Madri, J., and H. Furthmayr. 1980. Collagen polymorphism in the lung. An immunohistochemical study of pulmonary fibrosis. Hum. Pathol. 4:353-366.

5. Snider, G. L., B. R. Celli, R. H. Goldstein, J. J. O'Brien, and E. C. Lucey. 1978. Chronic interstitial pulmonary fibrosis produced in hamsters by endotracheal bleomycin: lung volumes, volume pressure relations, carbon monoxide uptake and blood gas studies. Am. Rev. Respir. Dis. 117:289-297.

6. Phan, S. H., R. S. Thrall, and C. Williams. 1981. Bleomycininduced pulmonary fibrosis effect of steroid on lung collagen metabolism. Am. Rev. Respir. Dis. 124:428-434.

7. Pickrell, J. 1981. In Lung Connective Tissue: Location, Metabolism and Response to Injury. CRC Press, Inc., Boca Raton, FL. 1-224.

8. Goldstein, R. H., E. C. Lucey, C. Franzblau, and G. L. Snider. 1979. Failure of mechanical properties to parallel changes in lung connective tissue composition in bleomycin-induced pulmonary fibrosis. Am. Rev. Respir. Dis. 120:67-73.

9. McCullough, B., J. F. Collins, W. G. Johanson, and F. L. Grover. 1978. Bleomycin-induced diffuse interstitial pulmonary fibrosis in baboons. J. Clin. Invest. 61:79-88.

10. Cantor, J. O., B. A. Bray, S. F. Ryan, I. Mandl, G. M. Mandl, and G. M. Turino. 1980. Glycosaminoglycans and collagen synthesis in nitroso- $n$-methylurethane-induced pulmonary fibrosis. Proc. Soc. Exp. Biol. Med. 164:1-8.

11. Karlinsky, J. B. 1982. Glycosaminoglycans in emphysematous and fibrotic hamster lungs. Am. Rev. Respir. Dis. 125:85-88.

12. Cantor, J. O., M. Osman, J. M. Cerrata, I. Mandl, and G. M.
Turino. 1983. Glycosaminoglycan synthesis in explants derived from bleomycin-treated fibrotic hamster lungs. Proc. Soc. Exp. Biol. Med. 173:362-366.

13. Zapol, W. M., R. L. Trelstad, J. W. Coffey, I. Tsai, and R. A. Salvador. 1979. Pulmonary fibrosis in severe acute respiratory failure. Am. Rev. Respir. Dis. 119:547-554.

14. Fulmer, J. D., R. S. Bienkowski, J. Cowan, S. D. Bruel, K. M. Bradly, V. Ferrans, W. C. Roberts, and R. G. Crystal. 1980. Collagen concentration and rates of synthesis in idiopathic pulmonary fibrosis. Am. Rev. Respir. Dis. 122:289-301.

15. Rennard, S. I., and R. G. Crystal. 1982. Fibronectin in human bronchopulmonary lavage fluid: elevation in patients with interstitial lung disease. J. Clin. Invest. 69:113-122.

16. Raghow, R., D. Gossage, J. M. Seyer, and A. H. Kang. 1984. Transcriptional regulation of type I collagen genes in cultured fibroblasts by a factor isolated from thioacetamide-induced fibrotic rat liver. J. Biol. Chem. 259:12718-12723.

17. Lowry, O. H., N. J. Rosebrough, A. L. Farr, and R. J. Randall. 1951. Protein measurement with the Folin phenol reagent. J. Biol. Chem. 193:265-275.

18. Burton, K. 1956. A study of the conditions and mechanisms of the diphenylamine reaction for the colorimetric estimation of deoxyribonucleic acid. Biochem. J. 62:315-323.

19. Przybyla, A. E., R. J. MacDonald, J. D. Harding, R. L. Pictet, and W. J. Rutter. 1979. Accumulation of the predominant pancreatic mRNAs during embryonic development. J. Biol. Chem. 254:2159.

20. Maniatis, T., E. F. Fritsch, and J. Sambrook. 1982. Molecular Cloning: A Laboratory Manual. Cold Spring Harbor Laboratory, Cold Spring Harbor, NY. 196.

21. Aviv, H., and P. Leder. 1972. Purification of biologically active globin messenger RNA by chromatography on oligothymidylic acid cellulose. Proc. Natl. Acad. Sci. USA. 69:1408-1412.

22. Thomas, P. S. 1980. Hybridization of denatured RNA and small DNA fragments transferred to nitrocellulose. Proc. Natl. Acad. Sci. USA. 77:5201-5205.

23. Davidson, J. M., S. Shibahara, M. P. Schafer, M. Harrison, C. Leach, P. Tolstoshev, and R. G. Crystal. 1984. Sheep elastin genes: isolation and preliminary characterization of a 9.9 kilobase genomic clone. Biochem. J. 220:643-652.

24. Thomas, P. S. 1983. Hybridization of denatured RNA transferred or dotted to nitrocellulose paper. Methods Enzymol. 100:255-266.

25. McKnight, G. S., and R. D. Palmitter. 1979. Transcriptional regulation of the ovalbumin and con-albumin genes by steroid hormones in chick oviduct. J. Biol. Chem. 254:9050-9058.

26. Chu, M. L., J. C. Myers, M. P. Bernard, J. F. Ding, and F. Ramirez. 1982. Cloning and characterization of five overlapping cDNAs specific for the human pro $\alpha 1$ (I) collagen chain. Nucleic Acids Res. 10:59255934.

27. Davidson, J. M., S. Shibahara, C. Boyd, M. L. Mason, P. Tolstoshev, and R. G. Crystal. 1984. Elastin mRNA levels during fetal development of sheep nuchal ligament and lung. Biochem. J. 220:653663.

28. Schwarzbauer, J. E., J. W. Tamkun, I. R. Lemischka, and R. O. Hynes. 1983. Three different fibronectin mRNAs arise by alternative splicing within the coding region. Cell. 35:421-431.

29. Cleveland, D. W., M. A. Lopata, R. J. MacDonald, N. J. Cowan, W. J. Rutter, and M. W. Kirschner. 1980. Number and evolutionary conservation of $\alpha$ and $\beta$-tubulin and cytoplasmic $\beta$ - and $\gamma$-actin genes using specific cloned cDNA probes. Cell. 20:95-105.

30. Birnboim, H. C., and J. Doly. 1979. A rapid alkaline extraction procedure for screening recombinant plasmid DNA. Nucleic Acids Res. 7:1513-1523.

31. Myers, J. C., L. A. Dickson, W. J. deWet, M. P. Bernard, M. L. Chu, M. de Liberto, G. Pepe, F. O. Sangiargi, and F. Ramirez. 1983. Analysis of the $3^{\prime}$ end of the human pro $\alpha 2$ (I) collagen gene. J. Biol. Chem. 258:10128-10135.

32. Schneike, A., K. Harbers, and R. Jaenisch. 1983. Embryonic 
lethal mutation in mice induced by retrovirus insertion into the $\alpha 1$ (I) collagen gene. Nature (London). 304:315-320.

33. Fuller, F., and H. Boedtker. 1981. Sequence determination and analysis of the $3^{\prime}$ region of chicken pro $\alpha 1$ (I) and pro $\alpha 2(\mathrm{I})$ collagen messenger ribonucleic acids including the carboxyterminal propeptide sequence. Biochemistry. 20:996-1006.

34. Seyer, J. M., E. T. Hutcheson, and A. H. Kang. 1976. Collagen polymorphism in idiopathic chronic pulmonary fibrosis. J. Clin. Invest. 57:1498-1507.

35. Clark, J. G., K. M. Kostal, and B. A. Marino. 1982. Modulation of collagen production following bleomycin-induced pulmonary fibrosis in hamsters: presence of a factor in lung that increases fibroblast prostaglandin $\mathrm{E}_{2}$ and cAMP and suppresses fibroblast proliferation and collagen synthesis. J. Biol. Chem. 257:8098-8105.

36. Clark, J. G., K. M. Kostal, and B. A. Marino. 1983. Bleomycininduced pulmonary fibrosis in hamsters. An alveolar macrophage product increase fibroblast prostaglandin $\mathrm{E}_{2}$ and cyclic adenosine monophosphate and suppresses fibroblast proliferation and collagen production. J. Clin. Invest. 72:2082-2091.
37. Bitterman, P. B., S. Adelberg, and R. G. Crystal. 1983. Mechanisms of pulmonary fibrosis. Spontaneous release of the alveolar macrophage-derived growth factor in the interstitial lung disorders. J. Clin. Invest. 72:1801-1813.

38. Tolstoshev, P., R. Haber, B. C. Trapnell, and R. G. Crystal. 1981. Procollagen messenger RNA levels and activity and collagen synthesis during the fetal development of sheep lung, tendon and skin. J. Biol. Chem. 256:9672-9679.

39. Raghow, R., and A. Granoff. 1983. Cell-free translation of frog virus 3 messenger RNAs. Initiation factors from infected cells descriminate between early and late viral mRNAs. J. Biol. Chem. 258:571578.

40. Banerji, S. S., N. G. Theodorakis, and R. I. Morimoto. 1984. Heat-shock-induced translational control of HSP70 and flobin synthesis in chicken reticulocyte. Mol. Cell. Biol. 11:2437-2448.

41. Farmer, S. R., K. M. Wan, A. Ben-Zeev, and S. Penman. 1983. Regulation of actin mRNA levels and translation responds to changes in cell configuration. Mol. Cell. Biol. 3:182-189. 